УAK $341.1 / .8$

ББК 67.91

DOI 10.22394/1682-2358-2018-5-123-128

N.N. Lipkina, Candidate of Sciences (Law), Docent of the International Law Department, Saratov State Academy of Law

\section{DETERMINING \\ THE CONTENT \\ OF THE JUS COGENS \\ NORMS ON HUMAN \\ RIGHTS IN THE \\ CONTEXT \\ OF THE APPLICABILITY \\ OF CIRCUMSTANCES, \\ PRECLUDING \\ WRONGFULNESS \\ OF AN ACT, IN INTERNATIONAL}

\section{LAW}

Through the example of the right to a fair trial and the prohibition of torture, the work reveals certain problems of determining the normative content of jus cogens norms. Special attention is paid to researching the issue of relevance of the content of jus cogens norms on human rights in the context of applicability of circumstances, precluding wrongfulness of an act, in international law.

Key words and word-combinations: human rights, jus cogens norms, circumstances precluding wrongfulness of conduct.
H.H. Мипкина, кандидат юридических наук, дочент кафедри международного права Сaратовской государственной юридической академuи (email:n_lipkina@list.ru)

ОПРЕАЕАЕНИЕ СОАЕРЖКАНИЯ HOPM JUS COGENS

O ПРАВАХ ЧЕ $\Lambda$ ОВЕКА

В КОНТЕКСТЕ ПРИМЕНИМОСТИ ОБСТОЯТЕАЬСТВ, ИСКАЮЧАЮЩИХ ПРОТИВОПРАВНОСТЬ АЕЯНИЯ, В МЕЖАУНАРОАНОМ ПРАВЕ

Аннотащия. На примере обращения к праву на справедливое судебное разбирательство и к запрету пыток выявляются отдельные проблемы определения нормативного содержания норм jus cogens. Особое внимание уделяется исследованию значения определения содержания норм јus cogens о правах человека в контексте применимости обстоятельств, исключающих противоправность деяния, в международном праве.

Ключевые слова и словосочетания: права человека; нормы jus cogens; обстоятельства, исключающие противоправность деяния.

K онцепция jus cogens в современном межаународном праве, несмотря на критику отдельных ее аспектов, представцяет

* Работа выполнена при поддержке гранта РФФИ № 18-011-00660 «Обстоятельства, исключающие противоправность деяния: анализ функционального значения и параметров применимости в международном праве прав человека». 
существенный интерес дия международного сообщества. В юридической китературе отмечается, что jus cogens направлены на создание международного правопорядка, в основе которого находится система права, сформированная на фундаментальных дмя международного сообщества ценностях, характеризующаяся иерархией норм и не полностью зависящая от воли субъектов международного права [1, р. 273] . Практическая значимость концепџии подтверждается фактом постоянного обращения к соответствующим вопросам Комиссии международного права ООН, которая с 2015 г. работает над темой «Императивные нормы общего международного права (jus cogens)», исслеАуя историю развития конџепџии јus cogens [2] , правовую природу jus cogens, критерии, позволяющие квалифиџировать норму международного права как когентную [3], а также посмедствия, порождаемые jus cogens [4] .

В ст. 26 Проекта статей об ответственности государств за межкународнопротивоправные деяния 2001 г. (Аалее - Проект статей) предусмотрено, что ничто в его гл. 5, касающейся обстоятельств, исключающих противоправность, не искАючает противоправности мюбого деяния государства, которое не соответствует обязательству, вытекающему из императивной нормы общего межаународного права [5]. Аанное положение согласуется со ст. 53 Венской конвенции о праве международных договоров 1969 г., где содержится опредемение императивной нормы общего межАународного права (jus cogens): это норма, которая принимается и признается международным сообществом государств в целом; отклонение от нее недопустимо; она может быть изменена только посмедующей нормой общего межАународного права, носящей такой же характер [6].

Анализ данного определения нормы jus cogens позволяет выделить следующие основные характеристики когентных норм: во-первых, это нормы общего международного права; во-вторых, они принимаются и признаются международным сообществом государств в целом как нормы, отклонение от которых недопустимо; в-третьих, они могут быть изменены только последующими нормами общего межАународного права, носящими такой же характер. Кроме того, нормы, имеющие характер jus cogens, иерархически обладают высшей юридической силой [7, р. 73], явмяются универсально применимыми нормами и скужат дмя защиты основополагающих ценностей международного сообщества [2, п. 63] .

ОАна из таких безусловных ценностей - права человека [8], поэтому особое место среди норм, относящихся к категории jus cogens, занимают нормы, гарантирующие ряд основных прав и свобод человека. В науке подчеркивается, что конџепџия jus cogens может способствовать усилению защиты прав человека, позволяя преодолеть «барьер государственного суверенитета» в отношении наиболее значимых из таких прав [9, р. 24]. Общепризнанной явмяется квалификаџия в качестве jus cogens таких прав человека, как запрет пыток [10, § 99], принцип равенства переА законом, равной защиты закона и недискриминации $[11, \$ 101]$, запреты расовой дискриминации, апартеида, рабства $[12$, с. 424].

ОАнако, несмотря на то что ссылки на jus cogens нередко используются в 
межкународной практике, а сама категория получила правовое определение в Венской конвенции о праве международных Аоговоров, методика квалификаџии нормы международного права в качестве jus cogens, а соответственно, определение круга и содержания таких норм, остается преАметом Аискуссий в юридической теории и практике [13, с. 115].

В 2018 г. вниманию Комиссии международного права ООН Специальным докладчиком А. ТАади бым представлен третий доклаА по теме «Императивные нормы общего межаународного права (jus cogens)». ОАин из его раздемов посвящен изучению последствий императивных норм общего межАународного права (jus cogens) Аля права ответственности государства, включая такое последствие, как неприменимость обстоятельств, исключающих противоправность , в отношении деяний, совершенных в нарушение jus cogens. В рассматриваемом контексте интерес представцяет высказанный Специацьным Аокладчиком тезис о необходимости разграничения таких вопросов, как определение применимости обстоятельств, искиючающих противоправность, и нормативного содержания исследуемой императивной нормы $[4$, п. 81] .

Аанный тезис представляется справедиивым и в отношении сферы прав человека. В научной теории и межкдународной практике права человека часто признаются в качестве принципов права [14, с. 82; 15, с. 66-79; 16, с. 7]. Многие из них имеют сложную структуру и включают несколько аспектов. Например, право на справедиивое судебное разбирательство включает в себя как один из аспектов право на доступ к суду [17, \ 113]. При этом вопрос о квалификации в качестве jus cogens нередко решается отдельно в отношении каждого из этих прав. Так, Специальный трибунац по Аивану отмечац когентный характер как права на справедливое судебное разбирательство в целом [18, 68], так и права на доступ к суду [19, \29]. Право на Аоступ к суду признал когентной нормой и Межамериканский суд по правам человека [20, §131]. Вместе с тем Европейский суд по правам человека в постановлении по Аелу «Al-Dulimi and Montana Management Inc. v. Switzerland» подчеркнул, что гарантии справедиивого судебного разбирательства, вкцючая право на доступ к суау, которое применительно к спорам о гражданских правах и обязанностях относится к универсально признанным основным принџипам права, несмотря на их значимость, к нормам jus cogens не относятся [21, \$136].

Как показывает анализ межАународной практики и научных исследований, установление пределов нормы jus cogens о запрете пыток является непростой задачей. Остается открытым вопрос о том, включает эта норма только запрет пыток как таковых ици также иные аспекты - запрет высылки, право жертв пыток на компенсацию и другое. Европейский суд по правам человека исходит из того, что ст. 3 Конвенции о защите прав человека и основных свобод 1950 г., закрепляющая запрет пыток, подразумевает, среди прочего, обязательство не выАворять, не выдавать и не передавать киџо иным способом в то государство, где он может столкнуться с реацьной опасностью подвергнуться пыткам [22, \114]. Отнесение ст. 3 указанной Конвенции к числу тех ее статей, отступмение от соблюдения обязательств по которым в чрезвычайных ситуациях по ст. 15 этой Конвенции не Аопускается, а также отсутствие ограничительных 
оговорок в рамках данной статьи, является свидетельством восприятия разработчиками Конвенции рассматриваемого запрета как абсолютного в разцичных его аспектах, включая запрет высылки. Более того, в постановлении по делу «Al-Adsani v. The United Kingdom» Большая Палата Европейского суда по правам человека прямо признаца, что запрет пыток Аостиг статуса императивной нормы в межаународном праве [23, § 61]. МежАународный трибунал по бывшей Югославии, отметив, что запрет пыток явмяется нормой jus cogens, подчеркнул обширность данного запрета, вкцючающего также обязательство не высылать, не возвращать и не выдавать мицо в то государство, в котором миџо может оказаться под угрозой применения к нему пыток [24, \144]. В науке межкународного права также можкно встретить тезис о том, что запрет высыцки включается в содержание когентного запрета пыток [25, р. 118].

В то же время в Конвенции против пыток и Аругих жестоких, бесчеловечных или унижающих достоинство видов обращения и наказания 1984 г. обязательство по предупреждению пыток закреплено в ст. 2, запрет высылать,

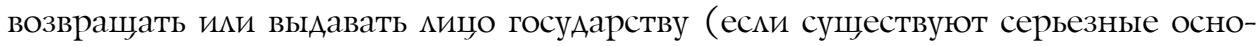
вания полагать, что ему может угрожкать там применение пыток) - в ст. 3, право на справедливую и адекватную компенсацию жертвам пыток - в ст. 14. Применительно к послеАнему праву данное обстоятельство рассматрива-

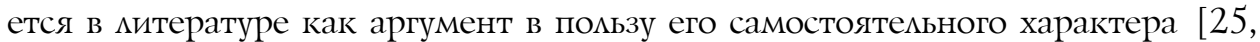
p. 107]. При таком подходе jus cogens характер соответствующих норм поАмежит установцению независимо Аруг от Аруга, а когентный характер самого запрета пыток не означает автоматического признания такого характера и у всех «смежкных» норм.

Анализируя п. 2 ст. 2 Конвенџии против пыток и Аругих жкестоких, бесчеловечных или унижающих достоинство видов обращения и наказания, согласно которому никакие искцючительные обстоятельства, какими бы они ни были, будь то состояние войны или угроза войны, внутренняя политическая нестабицьность или мюбое Аругое чрезвычайное положение, не могут служить оправданием пыток, Р. БоеА отметиц, что не является очевидным ответ на вопрос о том, распространяется $\Lambda$ Аанная оговорка о запрете Аерогации, сформулированная в отношении запрета пыток, на запрет высылки, содержащийся в ст. 3 Конвенции [26, р. 35]. Высказав сомнение относительно того, можно $\Lambda$ рассматривать положение о запрете высылки в качестве јus cogens [26, р. 33], ученый пришел к выводу о том, что не является очевидным, искАючает $и$ Конвенция против пыток и других жестоких, бесчеловечных или унижающих Аостоинство видов обращения и наказания ссылку на состояние необходимости как на обстоятельство, исключающее противоправность деяния, в отношении нарушения положения о запрете высылки (non-refoulement provision) [26, p. 35].

В рассматриваемом контексте ииния аргументации, используемая Р. БоеАом, обращает на себя внимание тем, что автор рассматривает вопрос о намичии у запрета высылки характера jus cogens автономно, даже не обращаясь к исследованию наличия когентного характера у запрета пыток. Кроме того, безусловный интерес представцяет также вывод Р. Боеда о том, что ссылка 
на состояние необходимости как обстоятельство, исключающее противоправность Аеяния, едва $и$ может быть искиючена в отношении запрета высылки в силу его когентного характера [26, р. 34]. Аанный вывоА, в совокупности с существующим разнообразием подходов к определению содержкания когентного запрета пыток, в частности к определению его соотношения с запретом высылки, как представляется, явцяется имлюстрацией к приведенному ранее тезису $\Lambda$. ТАади о том, что Аля определения применимости обстоятельств, исключающих противоправность (в контексте запрета ссылки на данные обстоятельства в отношении деяния, которое не соответствует обязательству, вытекающему из императивной нормы общего межАународного права), необходимо пристальное внимание уделять установлению нормативного содержания соответствующей императивной нормы.

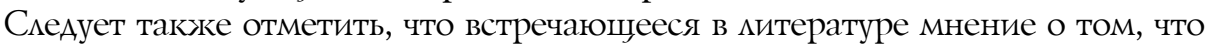
все права человека представцяют собой нормы jus cogens [27, р. 441-443], выглядит явно неоправданным и не отвечает современным реалиям развития межлународных отношений. Права человека имеют чрезмерно широкое и разнообразное содержкание, что способствует существенному развитию круга и содержкания соответствующих международных обязательств государства по обеспечению таких прав с течением времени. Именно поэтому реализация искцючения, установленного в ст. 26 Проекта статей, обусловлена необходимостью установцения когентного характера нормы межлународного права, закрепляющей конкретное межАународное обязательство государства по обеспечению соответствующего права человека, которому не соответствует деяние государства.

Таким образом, содержкащееся в ст. 26 Проекта статей условие является спещифическим узким критерием, не позволяющим применять указанные обстоятельства Аля искмючения противоправности отступлений от прав человека, имеющих характер jus cogens. Необходимо признать, что данный критерий не препятствует применению обстоятельств, исключающих противоправность, к иным нормам межкаународного права прав человека . Хотя этот вывод не предрешает вопроса о применимости таких обстоятельств ввиду наличия иных условий их применимости, его необходимо учитывать при оценке параметров взаимоАействия обстоятельств, искиючающих противоправность, и прав человека.

Аальнейшие исследования вопросов определения правовой природы jus cogens, а также методики квамификации норм в качестве таковых имеют существенное теоретическое и практическое значение, так как могут способствовать более структурированной правовой аргументаџии сторон в возникающих спорах, повышению правовой опреАеленности в межАународном юридическом процессе, укреплению межАународной законности.

\section{Библиографический список}

1. Petsche M. Jus Cogens as a Vision of the International Legal Order // Penn State International Law Review. 2010. Vol. 29. №. 2. P. 233-273.

2. First report on jus cogens to International Law Commission by D. Tladi, Special Rapporteur, 2016. URL: http://legal.un.org/docs/?symbol=A/CN.4/693 
3. Second report on jus cogens to International Law Commission by D. Tladi, Special Rapporteur, 2017. URL: https://undocs.org/en/A/CN.4/706

4. Third report on peremptory norms of general international law (jus cogens) to International Law Commission by D. Tladi, Special Rapporteur, 2018. URL: https://undocs.org/en/A/CN.4/714

5. Ответственность государств за международно-противоправные деяния: Резолюция Генеральной Ассамблеи ООН № 56/83 от 12 дек. 2001 г. URL: https://undocs.org/ru/A/RES/56/83

6. Венская конвенция о праве международных договоров 1969 г. // Ведомости Верховного Совета СССР. 1986. № 37. Ст. 772.

7. Hossain K. The Concept of Jus Cogens and the Obligation Under The U.N. Charter // Santa Clara Journal of International Law. 2005. Vol. 3. Issue 1. P. 72-98.

8. Ryngaert C. State Responsibility, Necessity and Human Rights. 2009. URL: https://www.law. kuleuven.be/iir/nl/onderzoek/working-papers/WP141e.pdf

9. Zenović $P$. Human rights enforcement via peremptory norms - a challenge to state sovereignty. Riga, 2012. URL. https://www.rgsl.edu.lv/uploads/research-papers-list/17/rp-6-zenovic-final.pdf

10. ICJ. Questions relating to the Obligation to Prosecute or Extradite (Belgium v. Senegal): Judgment of 20 July 2012. URL: http://www.icj-cij.org/files/case-related/144/144-20120720-JUD01-00-EN.pdf

11. Inter-American Court of Human Rights. Juridical Condition and Rights of Undocumented Migrants: Advisory Opinion (OC-18/03), 17 September 2003.

12. Доклад Комиссии международного права 2006 г. URL: http://undocs.org/ru/A/61/10

13. Красиков Д.В. Конвенционно-конституционные коллизии и иллюзии: что лежит в основе «возражения» Конституционного Суда России в адрес Европейского Суда по правам человека? // Международное правосудие. 2016. № 3 (19). С. 101-117.

14. Кононов А.Л. Об общих принципах права во Французской и Бельгийской судебной практике по административным делам // Государство и право. 2001. № 3. С. 82-86.

15. Тиунов О.И. Предмет, система и принципы международного права окружающей среды // Журнал российского права. 2013. № 6 (198). С. 66-79.

16. Гуляева E.E. Правовые основания ограничения права на свободу и личную неприкосновенность по Конвенции о защите прав человека и основных свобод 1950 г.: автореф. дис. ... канд. юрид. наук. Саратов, 2011.

17. ECtHR. Nant-Liman v. Switzerland (GC) (appl. no. 51357/07), 15 March 2018.

18. Special Tribunal for Lebanon. The Prosecutor v. Salim Jamil Ayyash, Mustafa Amine Badreddine, Hussein Hassan Oneissi, Assad Hassan Sabra: Decision on the defence appeals against the Trial Chamber's «Decision on the defence challenges to the jurisdiction and legality of the Tribunal» of 24 October 2012.

19. Special Tribunal for Lebanon. The Prosecutor v. Jamil El Sayed: Order Assigning Matter to Pre-trial Judge of 15 April 2010.

20. Inter-American Court of Human Rights. Goiburb et al. v. Paraguay: Judgment of September 22, 2006

21. ECtHR. Al-Dulimi and Montana Management Inc. v. Switzerland (GC) (appl. no. 5809/08), 26 November 2013.

22. ECtHR. Hirsi Jamaa and Others v. Italy (GC) (appl. no. 27765/09), 23 February 2012.

23. ECtHR. Al-Adsani v. The United Kingdom (GC) (appl. no. 35763/97), 21 November 2001.

24. ICTY. Prosecutor v. Furundhija (case No. IT-95-17/1-T): Judgement of 10 December 1998.

25. De Wet $E$. The Prohibition of Torture as an International Norm of jus cogens and Its Implications for National and Customary Law // European Journal of International Law. 2004. Vol. 15, № 1. P. 97-121.

26. Boed $R$. State of Necessity as a Justification for Internationally Wrongful Conduct // Yale Human Rights and Development. 2000. Vol. 3(1). Article 1. P. 1-43.

27. Parker K. Jus Cogens: Compelling the Law of Human Rights // Hastings International and Comparative Law Review. 1989. Vol. 12, № 2. P. 411-463. 